\title{
Croatian Strategy for the Development of Public Administration for the period from 2015 to 2020
}

\author{
Leda Lepri \\ Assistant Minister \\ Ministry of Public Administration \\ Maksimirska 63, Zagreb, Croatia \\ Leda.Lepri@uprava.hr
}

\section{Introduction}

The information and communications technology (hereinafter referred to as ICT) plays the leading role in the transformation of citizens' lifestyle, thus transforming the society as a whole. ICT as a generic term encompasses various types of information and communications technologies which enable the generation, storage, processing and exchange of information.

The potential of "the digital" for economic development and improvement of citizens' lifestyle is enormous, since everything is being recognized on an international level more and more quickly. Advanced public administrations have been exploring the ways of using this potential under their respective national circumstances.

\section{Objectives}

1. Improved business productivity of public administration through the use of ICT and new skills;

2. Enhanced quality of life through the use of public administration e-services;

3. Improved relationship between citizens and state administration through ICT use;

4. Insurance of secure environment for the provision of public administration e-services;

5. Increased competitiveness of economy through the use of public administration e-services

6. Opening up space for ICT-based innovations in public administration through the cooperation of public administration, scientific and business entities, and

7. Inclusion in the European Administrative Space.

Moreover, the quality and accessibility of public services in isolated and remote locations, especially on islands, has been lagging significantly behind other areas. There is a need to provide adequate services to the population, and the easiest way to do it is via the Internet. The problem of accessibility also concerns people with disabilities, vulnerable and socially endangered groups, including war veterans. Additional efforts are needed to adjust e-services to different 
groups of people with disabilities and to adapt e-content in order to ensure the accessibility of the services for everyone. This will result in the creation of equal conditions and possibilities for the use of e-public services and the Internet for the entire population.

Pursuant to the Decision of the Croatian Government of 2 February 2012, the Commission for the Coordination of Public Sector Informatisation was established with the aim to rationalise the system and simultaneously enhance the quality of public services. The National Information Infrastructure Act (OG 92/2014) (hereinafter: the Act) was adopted by the Croatian Parliament in July 2014, as a response to the need to change the functioning of public administration and its relation towards citizens and businesses, and with the aim to ensure e-public services for citizens and businesses which are based on an integrated national information system.

In November 2014, the Croatian Government adopted the Decree Establishing the Public Register for the Coordination of National Information Infrastructure Projects (Public Register ProNII).

The Public Register ProNII was established for the purpose of rationalisation, steering of development and coordination of all activities and projects related to the application of national information infrastructure, simultaneously increasing the quality of public services and preventing the planning and implementation of the equal or similar projects in the public sector.

In order to solve problems in the state IT system management (in the sense of inadequate and insufficiently efficient cost and investment management in the IT sector), the Croatian Government has proposed that a single Shared Services Centre be established, thus setting up a single strategic location for the management and coordination of the development of the state IT; rationalising state IT expenses through supervision over the spending of budget resources; consolidating the integration of the IT systems of different state bodies, and enabling the use of a unified IT infrastructure. Consequently, public sector bodies could focus more on their basic activity and align their work with other public sector bodies by standardising common business processes through the unified IT system. Such a manner of work would lead to a new dimension in the transparency of the system and to creating new business possibilities for the private sector.

\section{Snapshot}

The current situation in Croatia is such that a vast majority of e-services is still at the maturity level 2, i.e. the level of one-way interaction. The reason for this is that until the summer 2014 there was no single point in the virtual world for interaction with citizens and businesses, so that every authority which wanted to provide personalised services needed to develop its own system of issuing mechanisms for the verification of eIdentity. 
Almost all public sector bodies have developed e-services. On 10 June 2014 the eCitizens platform was launched with the three main components:

- Central Government Portal system,

- National Identification and Authentication System,

- Personal User Box system.

Problems of the dispersion of information and e-services, was resolved by introducing the system of a central government portal which integrates information and e-services in one place - the Central Government Portal which is realised within a single domain: gov.hr.

National Identification and Authentication System NIAS is the single point of eIdentity verification for access to e-services. The basic function of NIAS is secure eIdentification and authentication of e-service users.

Electronic credentials currently available through the NIAS system are as follows:

- ePass user name and password - a system developed for eCitizens;

- mToken - application developed for smartphones - a system developed for eCitizens;

- smart card of the Croatian Health Insurance Institute (CHII);

- user name and password from the AAI@EDU system - existing system of primary, secondary and higher education;

- HPB Token/mToken, and

- ePost (user name and password) - Croatian Post

The Open Data Portal of the Republic of Croatia, modelled on other similar projects in Europe and the world, represents a catalogue of metadata (data which describe sets of data more closely), and it helps users to get to desired open data easily. The portal was established at the address https://data.gov.hr.

The interoperability system in the Republic of Croatia is still in development. It should ensure interconnection of information systems developed on the principle of silos into a single system which will ensure the surpassing of legal, organisational, technical and semantic barriers in the development of national information infrastructure.

The ProNII Public Register serves to build interoperable solutions and to rationalise expenses in the development of public sector information systems in such a way that it guarantees control over projects, and on that basis decisions are made on joint project implementation, while preventing the planning and implementation of overlapping projects.

The public register Metaregister is also in place, functioning as a collaboration tool for the development of the system of interconnection of public registers. Apart from the entry of all the existing ways and possibilities of interconnection, the Metaregister ensures coordination during changes in the system of registers, and creates the so-called referential integrity. 
Table 1: SWOT analysis of public administration ICT

\begin{tabular}{|c|c|}
\hline STRENGTHS & WEAKNESSES \\
\hline $\begin{array}{l}\text { - Strong political commitment to building a } \\
\text { modern, efficient and transparent public } \\
\text { administration system, the aim of which is } \\
\text { to ensure access for citizens and businesses } \\
\text { to high quality services and coherent and } \\
\text { reliable data through ICT } \\
\text { - Existing strategic framework for the devel- } \\
\text { opment of e-services and applications in } \\
\text { sectoral strategies (and the Public Admin- } \\
\text { istration Development Strategy), with an } \\
\text { additional advantage of the Digital Growth } \\
\text { Strategy } \\
\text { Common rules for national information } \\
\text { infrastructure development and implemen- } \\
\text { tation of projects related to the National In- } \\
\text { formation Infrastructure Act will be defined } \\
\text { through secondary legislation }\end{array}$ & $\begin{array}{l}\text { A relatively low level of e-services provi- } \\
\text { sion and use, and their low adaptability to } \\
\text { the needs of individual users in relation to } \\
\text { the EU average } \\
\text { - Lack of a coordination mechanism for ICT } \\
\text { projects in central government and local and } \\
\text { regional self-government } \\
\text { Lack of a Chief Information Officer for stra- } \\
\text { tegic thinking and introduction of ICT and } \\
\text { e-services in public administration bodies, } \\
\text { who would answer directly to the head of a } \\
\text { body }\end{array}$ \\
\hline OPPORTUNITIES & THREATS \\
\hline $\begin{array}{l}\text { Around } 130 \mathrm{~m} \text { Euros from EU structural } \\
\text { funds available in the period 2014-2020 for } \\
\text { investments in public e-services develop- } \\
\text { ment and public administration informatisa- } \\
\text { tion } \\
\text { - Education and motivation of users for the } \\
\text { use of e-services } \\
\text { - Entry of new "digital natives", children } \\
\text { raised with ICT }\end{array}$ & $\begin{array}{l}\text { Change in government policies and priori- } \\
\text { ties related to the public administration } \\
\text { modernisation and informatisation process, } \\
\text { and consequent discontinuity in the imple- } \\
\text { mentation of government programmes and } \\
\text { projects } \\
\text { - Lack of IT experts in the labour market, } \\
\text { especially in the public administration } \\
\text { Public fear over information security and } \\
\text { personal data protection }\end{array}$ \\
\hline
\end{tabular}

\section{e-Croatia 2020 - strategic objectives, activities and indicators}

The goal of this Strategy is to ensure the development of the highest possible number of complex e-services oriented towards citizens and businesses in a standard manner. Complex, user-oriented e-services will be developed on an integrated national information system by respecting the basic principle of "only once" (the citizen delivers data only once, after that they are transferred), defined by the National Information Infrastructure Act, in cooperation of all central state administration bodies.

The strategic goal of the Strategy is to develop e-services required by citizens and businesses, and thus to increase the number of citizens using complex public administration e-services.

Activities of the Strategy with respect to external users - The objective is to increase the proportion of public e-services in the overall number of public administration services. The development of the e-services system will be based on the European Interoperability Framework. Special attention will be paid to 
the political context as well as legal, organisational, semantic and technical interoperability.

\section{Key areas and activities}

The development of user e-services will go in the direction of the following key areas: rule of law and security; labour market and education; cultural and national heritage; health sector; war veterans; taxes and customs; agriculture and rural development.

The Republic of Croatia has chosen to establish a Shared Services Centres which will offer sharing of technical and business services. Shared resources will be available to a large number of users who will only have to take care of their own devices. This will enable dynamic scalability, operational speed and easy change of suppliers and services. The government cloud is a programme which will the ensure the use of a series of services in the cloud, and which represents a shift in the way we procure and work with information and communications technology.

\section{Effects of the implementation of the Strategy}

Implementation of the Strategy will primarily affect the life of citizens. Interaction with the public administration is not the purpose of the existence of citizens and businesses, so that it should be reduced to the necessary minimum, and their needs should be satisfied within the set time limit. Public administration informatisation will affect services by making them precise, legal, timely and transparent, and provided through the channel which is most convenient for citizens and businesses. By using e-services, the entire Croatian population is getting used to using new technologies and increasing their value in the labour market. 